\title{
Working
}

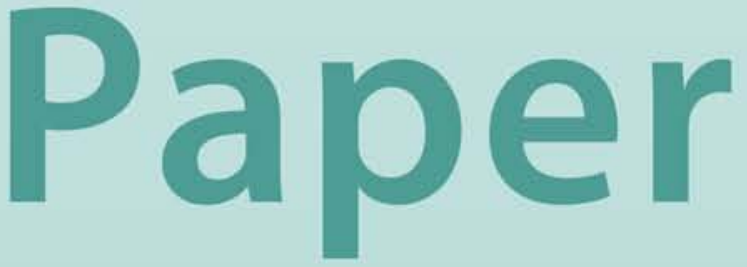




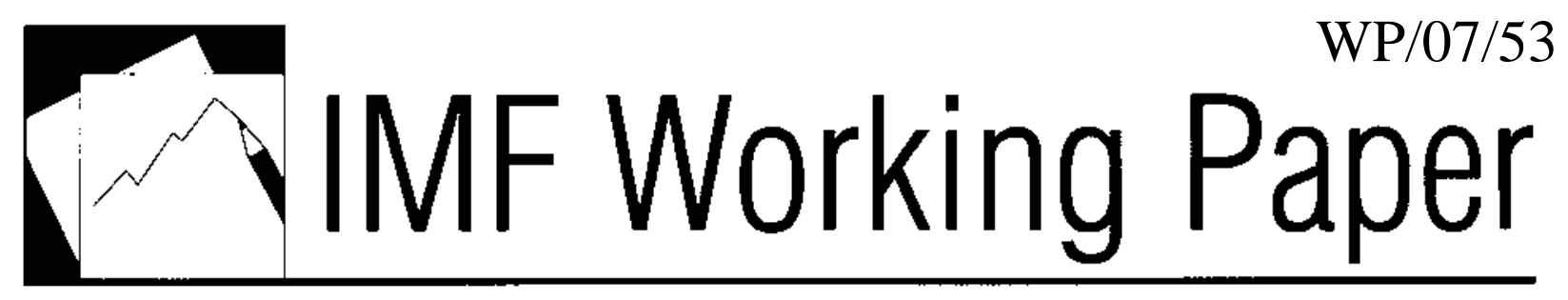

Are Regional Trade Agreements in Asia Stumbling or Building Blocks?

Implications for the Mekong-3 Countries

Patrizia Tumbarello

INTERNATIONAL MONETARY FUND 


\title{
IMF Working Paper
}

APD

\section{Are Regional Trade Agreements in Asia Stumbling or Building Blocks? Implications for the Mekong-3 Countries}

\author{
Prepared by Patrizia Tumbarello ${ }^{1}$ \\ Authorized for distribution by Lazaros Molho
}

March 2007

\begin{abstract}
This Working Paper should not be reported as representing the views of the IMF. The views expressed in this Working Paper are those of the author(s) and do not necessarily represent those of the IMF or IMF policy. Working Papers describe research in progress by the author(s) and are published to elicit comments and to further debate.

Is the recent proliferation of Regional Trade Agreements (RTAs) in Asia a healthy development, or runs the risk of turning into an unmanageable "noodle bowl" in the future? The goal of this paper is to shed some light on this question. The results show that membership in the Asian RTAs considered in this study have not, to date, occurred at the expense of trade with nonmembers, as most Asian countries' integration with the global economy preceded regional integration. However, looking forward, given their discriminatory nature, a proliferation of RTAs, which is not accompanied by continuing unilateral and multilateral liberalization, could run the risk of leading to costly trade diversion.

JEL Classification Numbers:C21, C23, F14, F15, O24

Keywords: regional trade agreements, gravity model, trade diversion, Asia, Mekong countries, panel data

Author’s E-Mail Address: ptumbarello@imf.org

\footnotetext{
${ }^{1}$ The author is indebted to Emanuele Baldacci, Ben Bingham, Josh Felman, Tabagus Feridhanusetyawan, Mikis Hadjimichael, Hanks Peter Lankes, Brad McDonald, Lazaros Molho, Tom Rumbaugh, Jennifer Steele, Ben Sutton, Masahiko Takeda, Man-Keung Tang, Jérôme Vandenbussche, Shang-Jin Wei, and Yi Wu for their helpful comments. Special thanks to Tran Duc Minh, Fred Burke, Somchith Inthamith, Masahiro Kawai, Fukunari Kimura, Vo Tri Than, and all the other participants at the Conference "Accelerating Development in the Mekong RegionThe Role of Economic Integration” held in Siem Reap (Cambodia) on June 26-27, 2006 for their valuable comments and suggestions.
} 


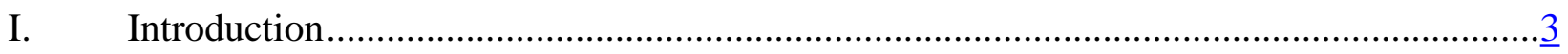

II. Benefits and Potential Risks of Regional Trade Integration Initiatives...............................

III. Selected Regional and Bilateral Trade Arrangements in the Asia and Pacific Region ........ $\underline{6}$

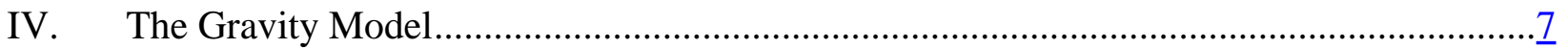

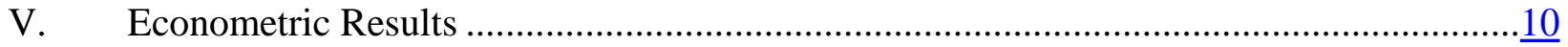

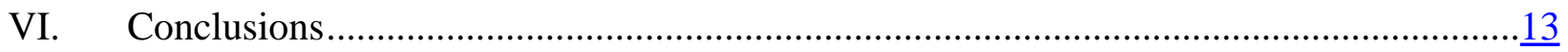

Tables

1. Preferential Trade Agreements in Force in the Asia and Pacific Region, February 2007........................................................................................ 15

2. ASEAN Members: Simple Average Most-Favored-Nation Tariff Rates ......................... $\frac{15}{15}$

3. Simple Average Most-Favored-Nation Tariff Rates.........................................................

4. WTO Accession Status, February 2007 …………………………………………...

5. Pooled Estimations of the Gravity Model with Importers-and Exporters-Fixed Effects, 1984-2005 ………………..........................................

6. Pooled Estimations of the Gravity Model: Gross Intra-Trade Effects, 1984-2005 ........18

7. Cross-Section Estimations of the Gravity Model with Importers-and Exporters-Fixed Effects, 1984-2005 ...........................................................................19

Figures

1. Preferential Trade Agreements in Force in the Asia and Pacific Region, February 2007 ...........................................................................20

2. Evolution of Exports Within and Outside the Region, 1984-2005 ………………….....21

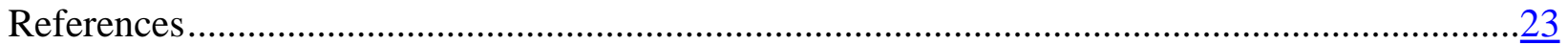

\section{Annexes}

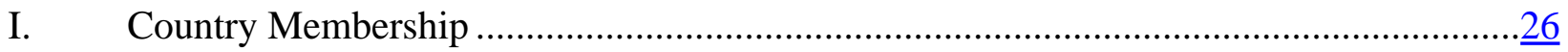

II. Summary of Recent Empirical Literature on Trade Creation vs. 


\section{INTRODUCTION}

Preferential trade agreements are proliferating around the world, including in Asia and the Pacific region. ${ }^{2}$ At least 26 such agreements involving Asian economies have entered into force since 2001 (Table 1), and currently about 70 additional ones are under negotiation or discussion. Unlike other regions, most regional preferential agreements in Asia followed, rather than preceded, trade reforms on a most-favored nation (MFN) basis. ${ }^{3}$ Regional trade integration is only one of the multiple facets of enhanced cooperation initiatives in the region that have come about since the Asian crisis.

The upsurge in Regional Trade Agreements (RTAs) around the globe reflects both economic and non-economic motivations. RTAs can be a cornerstone of larger economic and political efforts to increase regional cooperation beyond the multilateral agenda. They can also stimulate inward foreign direct investment (Kimura and Ando, 2005) and growth through technological transfers. Their proliferation can also be motivated by a growing sense that regional agreements elsewhere put the left-out countries at a disadvantage (Baldwin, 1993); and sometimes there may also be a perception that WTO accession is time-consuming. However, it is important to recognize that, as a discriminatory measure, RTAs can also be harmful, both to member countries and excluded countries, especially when they are pursued not as a complement, but as a substitute for multilateral liberalization. In such circumstances, increased protection of vested interests can turn the agreements into closed blocs, discouraging multilateralism, and distorting the pattern of international trade.

Consequently it is useful to ask whether the recent proliferation of preferential agreements in Asia is a healthy development, or runs the risk of turning into an unmanageable "noodle bowl". The goal of this paper is to shed some light on this question, and the main messages are as follows:

- Membership in the Asian RTAs considered in this study does not seem to have generally occurred at the expense of trade with nonmembers during 1984-2005, as most Asian countries’ integration with the global economy preceded regional integration.

- The above result appears more the effect of Asian countries’ strong inclination to pursue non-discriminatory liberalization, than the result of regionalism itself. In fact, while members of Asian RTAs seem to have recorded more trade with the rest of the world than other countries with similar characteristics in other regions, this effect was strongest for countries with the lowest MFN rates.

\footnotetext{
${ }^{2}$ By mid-2006, 211 preferential trade agreements were currently in force and notified to the WTO, with 27 of these notified over the past year. Another 65 were estimated to be operational but the WTO had not yet been notified.

${ }^{3}$ See Feridhanusetyawan (2005) for a comprehensive outlook of the Asia and Pacific preferential trade agreements.
} 
- Looking forward, a proliferation of RTAs, which is not accompanied by continuing unilateral and multilateral liberalization, could run the risk of leading to suboptimal trade patterns. To guard against this risk, the Mekong $3^{4}$ countries - which have relatively higher MFN rates compared to the rest of the region (Table 2) — would be well-advised to continue to pursue broad-based trade liberalization, not only at the regional level, but also vis-à-vis the rest of the world on an MFN basis.

While it is beyond the scope of this paper to assess whether a pan-Asian free trade area would be preferable to several overlapping initiatives, a greater coherence among existing agreements, in terms of tariff preferences, rules of origin, ${ }^{5}$ and phase-in modalities would facilitate implementation, reduce administrative costs, and help minimize possible distortions in trade patterns.

The remainder of the paper is structured as follows: Section II discusses some benefits and potential risk of regionalism. Section III briefly reviews RTAs in the Asia and Pacific region considered in this study. Section IV presents a gravity model of trade used to assess how RTAs may have affected their members' trade pattern, and Section $\mathrm{V}$ provides the empirical results. Section VI concludes.

\section{BenEFits AND Potential Risks of Regional Trade INTEgRATion INITIATIVES}

Well-designed trade agreements can expand trade opportunities and benefit participants. RTAs can serve as a vehicle for dialogue and coordination on regional issues that are not part of the multilateral agenda. ${ }^{6}$ They can also strengthen political ties between countries in the region.

However, as a discriminatory tool, RTAs can potentially be harmful. In principle, preferential trade agreements are economically inferior to nondiscriminatory trade liberalization on a MFN basis. Indeed, there is a risk that RTAs could, over time, turn into closed blocs. RTAs could divert resources away from multilateral trade liberalization, both in presence of limited administrative capacity, or because they are incorrectly perceived as a proxy for multilateral liberalization, and could thereby delay WTO negotiations and accession (Tumbarello, 2005). Political economy considerations also suggest that RTAs could create incentives for regional trade partners to lobby against any MFN-based reforms that would reduce the value of their tariff preferences, thus undermining prospects for future broader trade reforms (Krueger, 1995, and Krishna, 1998).

\footnotetext{
${ }^{4}$ The Mekong 3 countries refer to Cambodia, Lao PDR, and Vietnam.

${ }^{5}$ Rules of origin are established in free trade agreements to ensure that only goods originating in participating countries enjoy preferences.

${ }^{6}$ These might include regulatory harmonization, infrastructure development, and collaboration among members to facilitate trade and transport.
} 
As second-best discriminatory policies, RTAs can give rise to welfare losses not only to third countries, but to the member countries themselves (Viner, 1950). RTAs may divert imports from nonmember sources whose production costs are lower to member suppliers, whose production costs may be higher. In such cases, the cost difference would be borne by the importing member (trade diversion effect). If, on the other hand, resources previously engaged in costly domestic production could be reallocated as a result of the RTA in the direction of countries' comparative advantage, economic welfare would increase (trade creation effect). The risk of net trade-diversion is more likely to be minimized (Krueger, 1995) if the rate of protection vis-à-vis nonmembers is low to start with, or if the RTA partners agree on a schedule of swift reductions in their MFN tariff over time, ideally to eventually match their preferential rates.

RTAs can also create a costly hub-and-spoke structure of trade. Such a structure can emerge when the largest RTA member or hub signs individual agreements with a wide range of peripheral countries or spokes, among which market access remains restricted. Such arrangements can marginalize the spokes, where market access conditions are usually less advantageous than in the hub, which enjoys improved access to all of the spokes. Such a scheme may generate lower gains among the spoke members, which will accrue mainly to the hub country (Wonnacott 1996 and Deltas et. al 2006).

Other concerns associated with proliferation of RTAs arise from the so-called "noodle bowl effect," which refers to the potential problems arising from lack of coherence among different overlapping agreements. For example, some individual members of the Association of Southeast Asian Nation (ASEAN) are negotiating bilateral agreements with non-ASEAN countries even if ASEAN itself negotiates with the same country. While the provisions of preferential agreements vary considerably, there has so far been little effort toward regulatory harmonization and consistency among them. As a result, restrictive and inconsistent rules of origin $^{7}$ across agreements can complicate outsourcing decisions by firms and add fragility to the trading system. Moreover, the outcome of a trade dispute between two members has the potential to spill over to other countries in the region and can create problems for other regional trade relations. In the absence of a regional dispute settlement mechanism, there is a potential risk of disruption in intra-regional trade. ${ }^{8}$ Differences on rules of origin are an important cause of inconsistency among Asian RTAs. For example, New Zealand-Singapore and the ASEAN Free Trade Area (AFTA) use 40 percent value-added criteria, while ASEAN-India, SingaporeIndia, and Japan-Singapore include multiple-change-of-tariff-heading criteria or other more complex provisions.

\footnotetext{
7 The administrative costs associated in proving conformity to these rules may lead to low utilization of the preferential trade scheme. Moreover, rules of origin can lead to trade diversion if they oblige partners to buy higher-priced intermediate goods from a partner rather than on the lower-priced world markets.
} 
To minimize the risks that RTAs can entail, it is important that they be implemented within a well-designed comprehensive framework. Best practice in designing RTAs includes: low external barriers and a continued commitment to MFN liberalization; open access to membership; consistency among different agreements; comprehensive coverage of goods with few exclusion; symmetrical and simple rules of origin with transparent and consistent regulations; behind-the-borders reforms to promote synergies and strengthen the supply response; and the establishment of dispute settlement provisions, to resolve conflict in a timely fashion (ADB, 2006, p. 290). Satisfying these conditions becomes increasingly difficult if RTAs continue to proliferate, however. ${ }^{9}$

\section{Selected Regional ANd Bilateral Trade ArRangements in the Asia AND PACIFIC REgION}

The empirical study undertaken in this paper focuses on assessing the implications of the following preferential trade agreements in Asia: the Association of Southeast Asian Nation (ASEAN), the Agreement on South Asian Association for Regional Cooperation (SAARC) Preferential Trading Arrangement (SAPTA), the Asia Pacific Economic Cooperation (APEC) Forum, and the Australia-New Zealand Closer Economic Relation (CER). ${ }^{10}$

ASEAN was established in 1967 to accelerate economic growth and promote peace and stability in the region. In January 1992, the creation of the ASEAN Free Trade Area (AFTA) was announced. AFTA six original members include: Brunei Darussalam, Indonesia, Malaysia, the Philippines, Singapore, and Thailand. Vietnam joined in 1995, Lao P.D.R. and Myanmar in 1997, and Cambodia in 1999. Its objective was to eliminate tariff and nontariff barriers among the Southeast Asian countries with a view to integrating the ASEAN economies into a regional market of more than 500 million people. AFTA has also a wide range of trade facilitation measures, including the ASEAN Agreements on Customs and Asian Customs Vision 2020, aimed at harmonizing and streamlining customs procedure among ASEAN members.

The agreement on the Common Effective Preferential Tariff (CEPT) scheme for AFTA required that tariff rates levied on a wide range of products traded within the region be progressively reduced to no more than 5 percent by 2003 for the six original members. A somewhat longer adjustment period was allowed for the four newer members, with Vietnam committed to reduce its CEPT to no more than 5 percent by 2006, Lao P.D.R. and Myanmar by 2008, and Cambodia

\footnotetext{
${ }^{8}$ See Baldwin (2006) on the fragility of East Asia regionalism caused by possible emerging tension among member countries.

${ }^{9}$ To assess whether it would be preferable to consolidate the Asian RTA into a single free trade area is beyond the scope of this paper. However, the need for greater coherence among regional schemes in Asia especially on rules of origin has been recently advocated (Mr. H. Kuroda, President Asian Development Bank, at the 39th Annual Meeting, Hyderabad, India, May 6, 2006).

${ }^{10}$ See Figure 1 for the preferential trade agreements involving Asia and Pacific countries.
} 
by 2010. All import duties are to be eliminated by 2010 for the former six countries and by 2015 for the latter four. ASEAN members have also the option of excluding products from the CEPT in three cases: temporary exclusions, sensitive agricultural products, and general exceptions.

ASEAN members have made significant progress in lowering intra-regional tariffs through the CEPT scheme for AFTA (Table 2). However, the actual implementation of AFTA rates appears to have been limited so far. This could reflect, in large part, the perceived high costs of administrative compliance and documentation, together with a long list of sensitive products and exceptions that are not subject to the preferential rates, which may discourage broad-based use of AFTA preferences.

The South Asian Association for Regional Cooperation (SAARC) was established in 1985 and includes: Afghanistan, Bangladesh, Bhutan, India, Maldives, Nepal, Pakistan, and Sri Lanka. In 1993, SAARC countries signed an agreement to gradually lower tariffs within the region and in 2002 they signed the South Asia Free Trade Agreement (SAFTA) which created a framework for the establishment of a free trade zone covering 1.4 billion people. This agreement went into force in January 2006.

The Asia Pacific Economic Cooperation (APEC) Forum is another regional initiative, which seeks to promote regional integration in tandem with continuing unilateral and multilateral liberalization. Since its inception, APEC has worked to reduce tariffs and other trade barriers across the Asia and Pacific region, and has been the cornerstone of a larger effort to deepen the policy dialogue and economic cooperation among countries in the region. The 1994 APEC Bogor Declaration was aimed at forming a free trade area in the region by 2010 for developed countries and by 2020 for developing countries. Rather than focusing on trade preferences, however, APEC trade liberalization is based on concerted unilateral liberalization in accordance with the MFN principle. The current APEC tariffs are, in fact, below the world average (Table 3) and declining.

The coverage of the Australia-New Zealand Closer Economic Relation (CER) is more comprehensive than AFTA, but its original focus was also on tariff reduction. Subsequently it has been revised several times to include services, trade facilitation, investment, and labor mobility.

\section{The Gravity Model}

A gravity model of trade is a useful framework for the assessment of the impact of RTAs on the pattern of bilateral trade flows. The model is based on the idea that trade between two countries is analogous to the gravitational force exerted between two objects. Thus, trade is a function of the countries' mass (in this case, GDP and GDP per capita) and the distance between them. A number of other explanatory variables are added to the basic equation as other determinants of bilateral trade flows (e.g., common border and language). Finally, this framework, augmented 
by the use of dummy variables to capture countries' participation in RTAs, makes it possible to estimate trade diversion or trade creating effects that RTAs may produce.

The gravity model emerged in the 1960s as an empirical specification without solid theoretical underpinnings (Tinbergen 1962, and Poyhonem 1993). Anderson (1979) and Bergstand (1985) provided the first clear microeconomic foundations of the model, still based on the old trade theory of a country' s comparative advantage, while in the mid-80s the "new trade theory" under perfect competition was also used to justify the gravity equation (Helpman and Krugman, 1985): a country is more likely to trade with economically larger countries that produce a greater variety of goods to offer, while GDP per capita also has a positive effect on trade, since as countries become more developed they tend to specialize more and, therefore, trade more.

The gravity equation used in this paper follows the specification of Soloaga and Winters (2001), but introduces important modifications - in particular it includes country-fixed effects (Subramanian and Wei, 2003, and Dee and Gali, 2003). It also controls for possible MFN liberalization on trade flows by introducing dummies on WTO membership, as in Subramanian and Wei (2003), and Rose (2004).

The following gravity model was estimated:

$$
\begin{aligned}
& \text { LnImports }_{i j}=\alpha+\beta_{1} \operatorname{LnGDP}_{i t}+\beta_{2} \operatorname{LnGDP}_{j t}+\beta_{3} \operatorname{Ln} \frac{G D P_{i t}}{\operatorname{Pop}_{i t}}+\beta_{4} \operatorname{Ln} \frac{G D P_{j t}}{P_{j t}}+\beta_{5} \operatorname{Ln}\left[\operatorname{Dist}_{i j}\right]+ \\
& \beta_{6} \operatorname{Ln}\left[A D J_{i j}\right]+\beta_{7} \operatorname{Ln}\left[\operatorname{Lang}_{i j}\right]+\sum_{k=1}^{n}\left[\gamma_{1, k} \text { RTA2 }_{i j t k}+\gamma_{2, k} \text { RTAimp }_{i t k}+\gamma_{3, k} \text { RTAexp }_{j t k}\right]+\gamma_{4} \text { WTO2 }_{i j t}+ \\
& \gamma_{5} \text { WTOimp }_{i t}+\gamma_{6} \text { WTOexp }_{j t}+\delta_{i t}+\varphi_{j t}+u_{i j t}+\alpha_{1 t}
\end{aligned}
$$

This specification regresses the (log of) imports of country $i$ from country $j$ (i.e., the dependent variable) on the economic size of the two countries, their level of development (proxied by their GDP per capita), the distance between the economic centers of the two countries, common border, and common language. ${ }^{11}$ In addition, the membership in each regional agreement is specified by three dummies as in Soloaga and Winters (2001), RTA2, where the suffix 2 implies that both countries, $i$ and $j$, are members of the same RTA, RTAimp, where the importer, country $i$, belongs to the RTA, irrespective of whether the exporter $j$ is a member of the RTA or not; and RTAexp, where the exporter, country $j$, belongs to the tested RTA, irrespective of whether the importer $i$ is a member of the RTA or not. ${ }^{12}$

\footnotetext{
${ }^{11}$ All the variables are expressed in logs, with the exception of the variable on the common border, common language, and the RTA dummies.

${ }^{12}$ RTA2-dummy takes the value 1 if both country $i$ and $j$ are members of the RTA, and zero otherwise. RTAimpdummy takes value 1 if the importing country $i$ is a member of the RTA, while the exporting country $j$ may or may not, and zero otherwise; and RTAexp takes value 1 when the exporting country $j$ is a member of the RTA, while
} 
The specification used aims to disentangle the effects of an RTA on bilateral trade flows between member and nonmember trading partners. In fact, differently from the first specifications of the gravity model that included only one dummy to capture RTA effects on intra-bloc trade - that is, the sum of Vinerian trade creation and trade diversion-this model, in line with the recent literature, uses two additional dummies to gauge the RTA effect on imports and exports with nonmembers. In doing so, it allows the identification of export and import diversion separately and provides an indication of whether an RTA is more likely to produce trade creation or trade diversion. Moreover, this model uses imports as dependent variable and not the sum of import and exports because using trade in both directions as dependent variable, as early studies did, constrains export to show the same pattern of diversion as imports. The introduction of dummies representing WTO membership aims at controlling for the effect of multilateral liberalization from the effect of regional integration (Table 4). The construction of the WTO three dummies is identical to the specification of the RTA-dummies (see footnote 12).

Importer-and exporter-fixed effects- $\delta_{i t}$ and $\varphi_{j t}$-capture all country-specific effects omitted from the rest of model specification (preferences, institutional framework etc). Hence, their inclusion avoids omitted variable bias identified by Wei (1996), Haveman and Hummels (1998), and Anderson and Van Wincoop (2003). Subramanian and Wei argue that incorporating time-varying importer and exporter-fixed effects serve to proxy for "multilateral resistance" discussed in Anderson and van Wincooop (2003). Trade between two countries depends not just on policy and barriers between them but also on the barriers between these countries and the rest of the world. Importer and exporter dummies are used as a proxy for the latter kind of barriers. Finally the specification also includes year specific dummies $\alpha_{1 t}$, as well as a normally distributed error term that has a zero mean and constant variance.

The coefficients of the RTA dummies (RTA2, RTAimp, and RTAexp) can be interpreted as follows:

- $\quad$ The coefficient $\gamma_{1}$ (when positive) can be interpreted as a measure of intra-regional bias: it represents how much more an RTA member trades with another member than with a nonmember.

- $\quad$ The coefficient $\gamma_{2}$ represents how much more one RTA member imports from its nonmember trading partners relative to what one would expect given their economic size, distance and other geographic and cultural characteristics. Analogous interpretation applies to the coefficient $\gamma_{3}$ on the export side. Positive coefficients could be taken as evidence of an open trade bloc. These coefficients can be interpreted as a measure of trade diversion, when the coefficients are negative.

importing country may or may not be a member, and zero otherwise. Moreover, as the number of members in some RTAs was not constant over the sample period, as some countries acceded at a later stage, we had included in the RTA-dummies the countries according to the year when they joined the agreement. 
- The sum of $\gamma_{1}+\gamma_{2}+\gamma_{3}$ represents how much the trade flow between two countries is raised if they are both members of the RTA. A positive sign suggests that an RTA tends to generate more trade among its members than any random country pair that does not belong to any RTA.

- The coefficient on the WTO2-dummy represents how much more a WTO member trades with another member than with a nonmember. We expect this coefficient to be positive. If members import more from other members than from nonmembers, this is interpreted to indicate that barriers against nonmembers are generally higher.

\section{Sample and Data}

The study considers the following preferential trade agreements with Asia: ASEAN, APEC, SAPTA, and the CER; and the following RTAs outside the region: the Eurasian Economic Community (EAEC), the European Union-comprising 15 members (EU-15); the Southern Common Market (Mercosur); and the North American Free Trade Agreement (NAFTA). Annex I spells out country membership of different groupings. The data set covers 182 countries for a total of 169,113 observations. Bilateral trade data are extracted from the UN COMTRADE database.

Two different sets of estimates were run. The first one uses a panel regression technique, which allows for year-specific effects, as well as importer-and exporter-fixed effects, covering the period 1984-2005 (Tables 5 and 6). The second one runs 10 separate annual cross-section regressions - one for each year-(Table 7) and it also includes exporter-and importer-fixed effects.

\section{ECONOMETRIC RESUlts}

The empirical estimates (Table 5) show that all standard gravity variables-economic size, per capita income, and bilateral distance, common language, and common border-are statistically significant at the 99 percent confidence level and have the expected signs. Distance between two countries appears to be the most important factor in determining trade flows. The results also suggest that, during 1984-2005, membership in major RTAs in Asia (ASEAN, APEC, and SAPTA) does not generally appear to have led to trade diversion, although this is not so clear for the case of members belonging to different overlapping agreements.

More specifically:

Members of ASEAN and SAPTA seem to have traded more than what the basic equation of the gravity model predicts - given their size, per capita income, geographic and linguistic characteristics - with both members and with nonmembers, suggesting that these RTAs are unlikely to have given rise to any trade diversion. This can be seen from the coefficients on the 
RTAexp and RTAimp dummies, which are both positive and statistically significant for all regional groups (Table 5, Regression 1$).{ }^{13}$ In the case of ASEAN, for example, bilateral intraASEAN trade has been estimated to be around 330 percent greater than trade between countries that do not belong to any RTA (Table 5 , regression 1 ). ${ }^{14}$

This outward-looking pattern of trade integration is stronger for ASEAN-6 countries, compared to the entire ASEAN group, consistent with the fact that ASEAN-6 members have lower MFN tariffs and more liberal trade regimes than the rest of the ASEAN group. This result emerges consistently in both pooled (Table 5, Regression 2) and cross-section estimations (Table 7), where the coefficients of ASEAN-6imp and ASEAN-6exp variables are higher than the corresponding coefficients of the ASEAN group. In particular the trade between two ASEAN-6 countries (Table 5, Regression 2) is estimated to be 5.2 times greater than that between any random country pair that does not belong to any RTA. ${ }^{15}$

ASEAN does not seem to have fostered trade flows among members to any greater extent than trade with nonmembers, quite the contrary. Trade between two ASEAN members is estimated to be 38 percent less than trade of ASEAN members with nonmembers. In fact, two ASEAN countries trade among themselves 3.3 times more than one would expect given their economic size, distance and other geographic and cultural characteristics. However, one ASEAN country trades with a non-ASEAN member even more $[\exp (1.256+0.683)-1=5.95]$, so that the intraregional bias (i.e., how much more an ASEAN member trades with another ASEAN member than with a nonmember), in this case is negative [exp $(-0.473)-1=0.38]$. Given that the coefficients that express the amount of trade with nonmember partners are higher than expected given the countries' economic characteristics, ASEAN countries appear to have succeeded in achieving a high degree of international integration, beyond regional integration.

When a dummy on APEC is introduced (Table 5, Regression 3), while both coefficients on the ASEAN export and ASEAN import dummies continue to be significant and positive, their magnitude diminishes substantially. This result suggests that it may be difficult to disentangle the extent to which the high degree of intra-regional trade is attributable to membership in either ASEAN of APEC, with seven of the ten ASEAN members also belonging to APEC.

\footnotetext{
${ }^{13}$ In the extreme case of trade diversion the sum of the coefficient of RTAimp and RTAexp would be negative indicating that the RTA depresses country imports from the rest of the world more than it increases its exports to the rest of the world or vice versa, so that the net effect on trade flows between RTA members and the world is negative.

${ }^{14}$ As the model was estimated in logs, the percentage change for a dummy is computed as [exp(dummy coefficient)-1]*100. In the case of ASEAN from Table 5 Regression 1: $[\exp (-0.473+1.256+0.683)-$ $1=3.3]^{* 100}=330$. The sum of the three coefficients of the RTA dummies $\left(\gamma_{1}, \gamma_{2}\right.$, and $\left.\gamma_{3}\right)$ is called by Soloana and Winters (2003) gross intra-trade effect. The corresponding values are reported in Table 6.

${ }^{15}[\exp (-0.188+1.276+0.749)-1=5.2]$
} 
In the case of the SAPTA, trade among members is higher than what would be expected, given the countries' economic characteristics. ${ }^{16}$ At first sight this seems to be in contrast with the stylized facts on trade flows presented in Figure 2 that suggest very low-intra regional trade among SAPTA members. However, after allowing for the effects of gravity model variables, especially GDP per capita, which is a proxy for economic development, the model suggests that SAPTA countries do not "undertrade" among them given that, with the exception of India, they are all low-income countries and therefore are not expected to trade as much as more advanced economies do. ${ }^{17}$ However, the SAPTA 2-dummy is not significant during 1985-2005; different specifications of the gravity model (Table 5, Regressions 1-4) suggest that SAPTA does not seem to have boosted intra-trade flows among its members to a significantly greater extent than trade with nonmembers.

The trade agreement between the two CER countries (i.e., Australia and New Zealand) seems to have increased trade between them beyond the effects of the general MFN liberalization. This can be seen from the positive and significant coefficient of the CER 2 dummy, which captures the extent to which the trade between the two members is more extensive than their trade with the rest of the world (Table 5, Regressions 1 and 2). However, when a dummy for APEC is added to the model and/or when other regional agreements around the world are taken into account (Table 5, Regressions 3 and 4), CER membership appears to have been associated with import trade diversion. This can be seen from the negative coefficient of the CER import dummy.

Membership in APEC was estimated to significantly expand trade between members as well as between members and the rest of the world (Table 5, Regressions 3 and 4). This is consistent with the expectation that APEC's open regionalism approach should have broadly based tradecreating effects.

The results of this study are in line with previous findings by Soloana and Winters (2001) and Clarete et al. (2002). ${ }^{18}$ However, for the case of ASEAN, they differ from previous results by Frankel and Wei (1997), which had found that membership in ASEAN was associated with a significant increase of intra-regional trade relative to trade with nonmembers. A possible explanation for the difference is that the ASEAN definition of this study, as well as of Soloana and Winters and Clarete et. al., also includes ASEAN late-comers Cambodia, Lao P.D.R., Myanmar, and Vietnam. Because these latter countries still have MFN tariffs above those of other ASEAN countries, their inclusion in the model may have diluted the trade-creating effects of ASEAN membership.

\footnotetext{
${ }^{16}[\exp (0.195+0.579+0.163)-1=1.5]$.

${ }^{17}$ More advanced economies according the theoretical underpinnings behind the gravity model tend to specialize more and, therefore, trade more.

${ }^{18}$ See Annex II for a summary of the recent empirical literature on gravity models in Asia.
} 
One main reason that could explain why RTAs in Asia appear to have not led to date to trade diversion is the fact that regional trade integration in Asia followed a long period of unilateral liberalization during the 1980s and 1990s. Subsequently, regional integration efforts proceeded in parallel with multilateral liberalization. In fact, many Asian countries acceded to the WTO in the mid-1990s, and lowered their MFN tariff rates substantially, thereby limiting the risk of possible trade diversion under subsequently agreed RTAs. Therefore variables that pick up changes in trade flows may be capturing the effects of lower MFN rates.

Another possible reason for the small estimated impact of ASEAN membership on intraregional trade could be the fact that only a limited amount of intra-ASEAN trade has been carried out so far under AFTA preferences, as reported recently by Baldwin (2006). AFTA's limited practical impact on trade flows to date is likely to be partly due to the high administrative costs associated with verifying that AFTA's rules of origin have been observed, which may often be perceived to be too large compared with the differential between the preferential CEPT rates and the corresponding MFN tariffs.

The reason why intra-ASEAN trade seems to be lower than expected after discounting for generalized trade openness also with nonmembers, despite the well-documented existence of regional supply chains, is that this model uses data based on total merchandise trade. International/distribution networks will be better detected by more disaggregated models of trade in machinery goods or even in machinery parts and components (see Kimura 2006).

The results also suggest that the members of RTAs in Asia-especially ASEAN and APECshowed a higher degree of openness vis-à-vis the rest of the world than other members of other RTAs outside the region (Table 5, Regression 4). Mercosur seems to have fostered intraregional trade, but also to have diverted imports from the world toward its member countries, while NAFTA countries are estimated to have traded about 60 percent less with the rest of the world than one would expect based on the standard gravity model. The last result, which is in line with the findings of previous studies, ${ }^{19}$ can be explained by the presence of significant complementarities in production among NAFTA countries, in contrast with the members of ASEAN and SAPTA, which have more similar comparative advantages.

\section{CONCLUSIONS}

Regional Trade Agreements are a prominent part of the Asia and Pacific's trade policy agenda and they can be an effective means to expand trade and increase cooperation in the region. But their discriminatory nature also entails some risks, and could give rise to costly trade diversion. The results of this paper, however, show that membership in the RTAs considered in this study does not seem to have generally occurred at the expense of trade with nonmembers during

\footnotetext{
${ }^{19}$ Wei, S., and J. Frankel (1997).
} 
1984-2005, as most Asian countries' integration with the global economy preceded regional integration, both at unilateral and at multilateral level.

The results of this study also reinforce the need for ASEAN members with more restrictive trade regimes, in particular the Mekong countries, to continue decreasing their MFN tariffs along with their ongoing integration in the regional markets. In fact, while continuing to enhance intra-Asian integration may be desirable, regional integration cannot be a substitute for multilateral and unilateral liberalization. Continuing unilateral and multilateral liberalization should serve to ensure that the region will reap the benefits from regional economic integration to the fullest extent possible without suffering from any significant trade diversion.

"There is little doubt that Asia's interests lie in an opening trading system among all nations of the world and that preferential arrangements with Asia would, in Asia's self-interest, need to be building blocks and not stumbling blocks to further global liberalization."20

As noted in a number of recent studies and reports, the negotiation and signing of multiple bilateral or regional trade arrangements could have serious adverse effects if regional integration ends up discouraging or retarding multilateral and unilateral liberalization. ${ }^{21}$ Moreover, membership in several bilateral and regional trade agreements which have mutually inconsistent rules of origin can substantially complicate production and sourcing decision by firms. An Asian Free Trade Area could potentially avoid some of the risks associated with proliferating RTAs. However, whether it would make sense to consolidate Asian RTAs into a single free trade area is a more complicated issue that would require further research and analysis.

\footnotetext{
${ }^{20}$ Krueger, A, 1997.

${ }^{21}$ Baldwin op.cit. and AsDB (2006).
} 
Table 1. Preferential Trade Agreements in Force in the Asia and Pacific Region, February 2007, 1/

\begin{tabular}{|c|c|}
\hline Regional Trade Agreements & Bilateral Trade Agreements \\
\hline AFTA (ASEAN Free Trade Area), 1992, 1993 & $\begin{array}{l}\text { Australia-New Zealand, (CER) 1983, } 1983 \text { 2/ } \\
\text { Australia-Singapore, 2003, } 2003\end{array}$ \\
\hline ASEAN-China Free Trade Agreement, 2004, 2005 & $\begin{array}{l}\text { Australia-Thailand, 2004, } 2005 \\
\text { Australia-United States, 2004, } 2005\end{array}$ \\
\hline Bangkok Agreement , 1975, 1976 & $\begin{array}{l}\text { China-Hong Kong SAR, 2003, } 2004 \\
\text { China-Macao SAR, 2003, } 2004\end{array}$ \\
\hline $\begin{array}{l}\text { Pacific Island Countries Trade Agreement (PICTA), 2001, } \\
2001\end{array}$ & $\begin{array}{l}\text { China-Thailand, 2003, } 2003 \\
\text { India-Sri Lanka , 1998, } 2001 \\
\text { India-Thailand, 2003, } 2004\end{array}$ \\
\hline SAARC Preferential Trade Agreement (SAPTA), & Japan-Malaysia, 2005, 2006 \\
\hline 1993, 1995 & $\begin{array}{l}\text { Japan-Mexico, 2004, } 2005 \\
\text { Japan-Singapore, 2002, } 2002\end{array}$ \\
\hline South Asia Free Trade Agreement (SAFTA), 2002, 2006 & $\begin{array}{l}\text { Korea-Chile, 2003, } 2004 \\
\text { Korea-EFTA, 2005, } 2006 \text { 3/ }\end{array}$ \\
\hline $\begin{array}{l}\text { Trans-Pacific Strategic Economic Partnership } \\
\text { Agreement (TPSEPA), 2005, } 2006\end{array}$ & $\begin{array}{l}\text { Korea-Singapore, 2005, } 2006 \\
\text { Lao PDR-United States, 2003, } 2005 \\
\text { Lao PDR-Thailand, 1991, 1991 } \\
\text { New Zealand-Singapore, 2000, } 2001 \\
\text { New Zealand-Thailand, 2005, } 2005 \\
\text { Singapore-EFTA, 2002, 2003 } \\
\text { Singapore-Jordan, 2004, } 2005 \\
\text { Singapore-United States, } 2003,2004 \\
\text { Sri Lanka- Pakistan, 2005, 2005 } \\
\text { Vietnam-United States, 2000, } 2001\end{array}$ \\
\hline
\end{tabular}

Source: Author's compilation.

$1 /$ The years refer respectively to the year of signing of the agreement and the year of entry into force.

2/ Closer Economic Relation.

3/ European Free Trade Association.

Table 2. ASEAN Members: Simple Average Most-Favored-Nation Tariff Rates (in percent) 1/

\begin{tabular}{lcc}
\hline & 1997 & 2006 \\
\cline { 2 - 3 } Brunei Darussalam & 3.1 & 4.8 \\
Cambodia & 18.0 & 14.9 \\
Indonesia & 13.0 & 7.0 \\
Lao P.D.R. & 9.6 & 9.7 \\
Malaysia & 8.1 & 8.1 \\
Myanmar & 5.8 & 5.6 \\
Philippines & 13.4 & 7.1 \\
Singapore & 0.0 & 0.0 \\
Thailand & 17.0 & 11.9 \\
Vietnam & 13.0 & 17.4 \\
Memorandum items 2/: & & \\
ASEAN & 10.2 & 8.7 \\
ASEAN-6, 3/ & 9.1 & 6.5 \\
Mekong-3, 4/ & 13.5 & 14.0 \\
World & 15.3 & 11.1 \\
\hline
\end{tabular}

Source: IMF Trade Policy Information Database (TPID), and ASEAN database.

1/ Most-Favored-Nation Rates apply to most imports from countries outside ASEAN.

2/ Average among member countries.

3/ Includes Brunei Darussalam, Indonesia, Malaysia, Philippines, Singapore, and Thailand.

4/ Includes Cambodia, Lao PDR, and Vietnam. 
Table 3. Simple Average Most-Favored-Nation Tariff Rates 1/ (in percent)

\begin{tabular}{lrr} 
& 1997 & 2006 \\
\hline APEC & 10.1 & 7.3 \\
ASEAN & 10.2 & 8.7 \\
CER & 5.5 & 3.2 \\
EAEC & 10.9 & 8.1 \\
EU-15 & 10.0 & 6.5 \\
MERCOSUR & 11.4 & 10.1 \\
NAFTA & 8.8 & 7.9 \\
SAPTA & 25.1 & 17.4 \\
Memorandum items: & & \\
ASEAN-6 & 9.1 & 6.5 \\
World & 15.3 & 11.1 \\
\hline SOure:
\end{tabular}

Source: IMF Trade Policy Information Database (TPID).

$1 /$ Average among member countries.

Table 4. WTO Accession Status, February 2007

\begin{tabular}{lc}
\hline Australia & Joined in 1995 \\
Bangladesh & Joined in 1995 \\
Bhutan & ongoing negotiations \\
Brunei Darussalam & Joined in 1995 \\
Cambodia & Joined in 2004 \\
China & Joined in 2001 \\
India & Joined in 1995 \\
Indonesia & Joined in 1995 \\
Japan & Joined in 1995 \\
Korea & Joined in 1995 \\
Lao PDR & ongoing negotiations \\
Malaysia & Joined in 2001 \\
Maldives & Joined in 1995 \\
Mongolia & Joined in 1997 \\
Myanmar & Joined in 1995 \\
Nepal & Joined in 2004 \\
New Zealand & Joined in 1995 \\
Pakistan & Joined in 1995 \\
Philippines & Joined in 1995 \\
Singapore & Joined in 1995 \\
Sri Lanka & Joined in 1995 \\
Thailand & Joined in 1995 \\
Vietnam & Joined in 2007 \\
\hline Source: WTO &
\end{tabular}

Source: WTO. 
Table 5. Pooled Estimations of the Gravity Model with Importers-and Exporters-Fixed Effects, 1984-2005 1/

\begin{tabular}{|c|c|c|c|c|}
\hline & $\begin{array}{l}\text { Regression } \\
\text { (1) }\end{array}$ & $\begin{array}{l}\text { Regression } \\
\text { (2) }\end{array}$ & $\begin{array}{l}\text { Regression } \\
\text { (3) }\end{array}$ & $\begin{array}{l}\text { Regression } \\
\text { (4) }\end{array}$ \\
\hline \multirow[t]{2}{*}{ InGDP i } & 0.902 & 0.902 & 0.881 & 0.863 \\
\hline & $(0.000)^{\star \star \star}$ & $(0.000)^{\star \star \star}$ & $(0.000)^{\star \star \star}$ & $(0.000)^{\star \star \star}$ \\
\hline \multirow[t]{2}{*}{ InGDP j } & 1.046 & 1.050 & 1.013 & 0.990 \\
\hline & $(0.000)^{\star \star \star \star}$ & $(0.000)^{\star \star \star \star}$ & $(0.000)^{\star \star \star \star}$ & $(0.000)^{\star \star \star}$ \\
\hline InGDP i per capita & $\begin{array}{c}0.083 \\
(0.000)^{\star \star \star}\end{array}$ & $\begin{array}{c}0.079 \\
(0.000)^{\star \star \star}\end{array}$ & 0.082 & 0.045 \\
\hline \multirow[t]{2}{*}{ InGDP j per capita } & 0.133 & 0.119 & 0.135 & 0.113 \\
\hline & $(0.000)^{\star \star \star}$ & $(0.000)^{\star \star \star}$ & $(0.000)^{\star \star \star}$ & $(0.000)^{\star \star \star}$ \\
\hline \multirow[t]{2}{*}{ In distance } & -1.324 & -1.319 & -1.375 & -1.392 \\
\hline & $(0.000)^{\star \star \star}$ & $(0.000)^{\star \star \star}$ & $(0.000)^{\star \star \star}$ & $(0.000)^{\star \star \star}$ \\
\hline common border & $\begin{array}{c}0.591 \\
(0.000)^{\star \star \star}\end{array}$ & $\begin{array}{c}0.607 \\
(0.000)^{\star \star \star}\end{array}$ & $\begin{array}{c}0.526 \\
(0.000)^{\star \star \star *}\end{array}$ & $\begin{array}{c}0.530 \\
(0.000)^{\star \star \star}\end{array}$ \\
\hline common language & $\begin{array}{c}0.959 \\
(0.000)^{\star \star \star}\end{array}$ & $\begin{array}{c}0.941 \\
(0.000)^{\star \star \star}\end{array}$ & $\begin{array}{c}0.903 \\
(0.000)^{\star \star \star}\end{array}$ & $\begin{array}{c}0.929 \\
(0.000)^{\star \star \star}\end{array}$ \\
\hline ASEAN imp & $\begin{array}{c}0.683 \\
(0.000)^{\star \star \star}\end{array}$ & $\begin{array}{l}\ldots \\
\ldots\end{array}$ & $\begin{array}{c}0.432 \\
(0.000)^{\star \star \star}\end{array}$ & $\begin{array}{c}0.379 \\
(0.000)^{\star \star \star}\end{array}$ \\
\hline ASEAN exp & $\begin{array}{c}1.256 \\
(0.000)^{\star \star \star}\end{array}$ & $\begin{array}{l}\cdots \\
\ldots\end{array}$ & $\begin{array}{c}0.886 \\
(0.000)^{\star \star \star}\end{array}$ & $\begin{array}{c}0.726 \\
(0.000)^{\star \star \star}\end{array}$ \\
\hline ASEAN 2 & $\begin{array}{c}-0.473 \\
(0.000)^{\star \star \star}\end{array}$ & $\begin{array}{l}\ldots \\
\ldots\end{array}$ & $\begin{array}{c}-0.605 \\
(0.000)^{\star \star \star}\end{array}$ & $\begin{array}{c}-0.568 \\
(0.000)^{\star \star \star}\end{array}$ \\
\hline CER imp & $\begin{array}{c}0.104 \\
(0.017)^{\star \star}\end{array}$ & $\begin{array}{c}0.111 \\
(0.011)^{\star \star}\end{array}$ & $\begin{array}{c}-0.133 \\
(0.004)^{\star \star \star}\end{array}$ & $\begin{array}{c}-0.086 \\
(0.063)^{\star}\end{array}$ \\
\hline CER exp & $\begin{array}{c}0.593 \\
(0.000)^{\star \star \star \star ~}\end{array}$ & $\begin{array}{c}0.603 \\
(0.000)^{\star \star \star *}\end{array}$ & $\begin{array}{c}0.231 \\
(0.000)^{\star \star \star \star}\end{array}$ & $\begin{array}{c}0.121 \\
(0.006)^{\star \star \star}\end{array}$ \\
\hline CER 2 & $\begin{array}{c}1.036 \\
(0.041)^{\star *}\end{array}$ & $\begin{array}{c}1.059 \\
(0.037)^{\star \star}\end{array}$ & $\begin{array}{l}0.727 \\
0.151\end{array}$ & $\begin{array}{l}0.743 \\
0.139\end{array}$ \\
\hline SAPTA imp & $\begin{array}{c}0.163 \\
(0.000)^{\star \star \star}\end{array}$ & $\begin{array}{c}0.156 \\
(0.000)^{\star \star \star}\end{array}$ & $\begin{array}{c}0.226 \\
(0.000)^{\star \star \star}\end{array}$ & $\begin{array}{c}0.259 \\
(0.000)^{\star \star \star}\end{array}$ \\
\hline SAPTA exp & $\begin{array}{c}0.579 \\
(0.000)^{\star \star \star}\end{array}$ & $\begin{array}{c}0.547 \\
(0.000)^{\star \star \star}\end{array}$ & $\begin{array}{c}0.679 \\
(0.000)^{\star \star \star}\end{array}$ & $\begin{array}{c}0.776 \\
(0.000)^{\star \star \star}\end{array}$ \\
\hline SAPTA 2 & $\begin{array}{l}0.195 \\
0.327\end{array}$ & $\begin{array}{l}0.192 \\
0.317\end{array}$ & $\begin{array}{l}0.085 \\
0.660\end{array}$ & $\begin{array}{l}0.036 \\
0.847\end{array}$ \\
\hline ASEAN-6 imp & $\begin{array}{l}\ldots \\
\ldots\end{array}$ & $\begin{array}{c}0.749 \\
(0.000)^{\star \star \star}\end{array}$ & $\begin{array}{l}\ldots \\
\ldots\end{array}$ & $\begin{array}{l}\ldots \\
\ldots\end{array}$ \\
\hline ASEAN-6 exp & $\begin{array}{l}\ldots \\
\ldots\end{array}$ & $\begin{array}{c}1.276 \\
(0.000)^{\star \star \star \star}\end{array}$ & $\begin{array}{l}\ldots \\
\ldots\end{array}$ & $\begin{array}{l}\ldots \\
\ldots\end{array}$ \\
\hline ASEAN-6 2 & $\begin{array}{l}\ldots \\
\ldots\end{array}$ & $\begin{array}{c}-0.188 \\
0.169\end{array}$ & $\begin{array}{l}\ldots \\
\ldots\end{array}$ & $\begin{array}{l}\cdots \\
\ldots\end{array}$ \\
\hline APEC imp & $\begin{array}{l}\ldots \\
\ldots\end{array}$ & $\begin{array}{l}\ldots \\
\ldots\end{array}$ & $\begin{array}{c}0.369 \\
(0.000)^{\star \star \star}\end{array}$ & $\begin{array}{c}0.554 \\
(0.000)^{\star \star \star}\end{array}$ \\
\hline APEC exp & $\ldots$ & $\cdots$ & $\begin{array}{c}0.578 \\
(0.000)^{\star \star \star}\end{array}$ & 0.958 \\
\hline APEC 2 & $\begin{array}{l}\cdots \\
\cdots \\
\cdots\end{array}$ & $\begin{array}{l}\cdots \\
\cdots \\
\cdots\end{array}$ & $\begin{array}{c}0.609 \\
(0.000)^{\star \star \star *}\end{array}$ & $\begin{array}{c}0.581 \\
(0.000)^{\star \star \star}\end{array}$ \\
\hline EU-15 imp & $\begin{array}{l}\ldots \\
\ldots\end{array}$ & $\begin{array}{l}\ldots \\
\ldots\end{array}$ & $\begin{array}{l}\ldots \\
\ldots\end{array}$ & $\begin{array}{c}0.599 \\
(0.000)^{\star \star \star}\end{array}$ \\
\hline EU-15 exp & $\ldots$ & $\ldots$ & $\ldots$ & 0.534 \\
\hline EU-15 2 & $\begin{array}{l}\cdots \\
\cdots\end{array}$ & $\begin{array}{l}\cdots \\
\cdots\end{array}$ & $\begin{array}{l}\cdots \\
\cdots\end{array}$ & $(0.000)^{\star \star \star}$ \\
\hline EAEC imp & $\begin{array}{l}\cdots \\
\cdots\end{array}$ & $\begin{array}{l}\cdots \\
\cdots\end{array}$ & $\begin{array}{l}\cdots \\
\ldots\end{array}$ & $\begin{array}{c}(0.000)^{\star \star \star} \\
-0.488\end{array}$ \\
\hline & $\ldots$ & $\ldots$ & $\ldots$ & $(0.000)^{\star \star \star}$ \\
\hline EAEC exp & $\ldots$ & $\ldots$ & $\ldots$ & 0.114 \\
\hline & $\ldots$ & $\ldots$ & $\ldots$ & $(0.007)^{\star \star \star}$ \\
\hline EAEC 2 & $\ldots$ & $\ldots$ & $\ldots$ & 2.70 \\
\hline & $\ldots$ & $\ldots$ & $\ldots$ & $(0.000)^{\star \star \star}$ \\
\hline Mercosur imp & $\ldots$ & $\cdots$ & $\cdots$ & -0.305 \\
\hline & $\ldots$ & $\ldots$ & $\ldots$ & $(0.000)^{\star \star \star}$ \\
\hline Mercosur exp & $\ldots$ & $\cdots$ & $\ldots$ & 0.937 \\
\hline & $\cdots$ & $\cdots$ & $\ldots$ & $(0.000)^{\star \star \star}$ \\
\hline Mercosur 2 & $\ldots$ & $\ldots$ & $\ldots$ & 0.747 \\
\hline & $\ldots$ & $\ldots$ & $\ldots$ & $(0.002)^{\star \star}$ \\
\hline NAFTA imp & $\ldots$ & $\ldots$ & $\ldots$ & 0.025 \\
\hline & $\ldots$ & $\ldots$ & $\ldots$ & 0.587 \\
\hline NAFTA exp & $\ldots$ & $\ldots$ & $\ldots$ & -0.973 \\
\hline & $\ldots$ & $\ldots$ & $\ldots$ & $(0.000)^{\star \star \star}$ \\
\hline NAFTA 2 & $\begin{array}{l}\ldots \\
\ldots\end{array}$ & $\ldots$ & $\begin{array}{l}\ldots \\
\ldots\end{array}$ & $\begin{array}{c}-0.339 \\
0.370\end{array}$ \\
\hline WTO imp & $\begin{array}{c}-0.910 \\
(0.000)^{\star \star \star}\end{array}$ & $\begin{array}{c}-0.843 \\
(0.000)^{\star \star \star}\end{array}$ & $\begin{array}{c}-0.981 \\
(0.000)^{\star \star \star}\end{array}$ & $\begin{array}{c}-0.993 \\
(0.000)^{\star \star \star}\end{array}$ \\
\hline WTO exp & $\begin{array}{c}-0.699 \\
(0.000)^{\star \star \star}\end{array}$ & $\begin{array}{c}-0.663 \\
(0.000)^{\star \star \star}\end{array}$ & $\begin{array}{c}-0.768 \\
(0.000)^{\star \star \star \star}\end{array}$ & $\begin{array}{c}-0.734 \\
(0.000)^{\star \star \star}\end{array}$ \\
\hline WTO 2 & 1.031 & 0.934 & 1.096 & 1.044 \\
\hline & $(0.000)^{\star \star \star}$ & $(0.000)^{\star \star \star}$ & $(0.000)^{\star \star \star \star}$ & $(0.000)^{\star \star \star}$ \\
\hline Constant & $\begin{array}{c}12.46 \\
(0.000)^{\star \star \star}\end{array}$ & $\begin{array}{c}12.42 \\
(0.000)^{\star \star \star}\end{array}$ & $\begin{array}{c}13.04 \\
(0.000)^{\star \star \star}\end{array}$ & $\begin{array}{c}13.21 \\
(0.000)^{\star \star \star}\end{array}$ \\
\hline Observations & 169,070 & 169,070 & 169,070 & 169,070 \\
\hline Adj. R-squared & 0.65 & 0.65 & 0.65 & 0.66 \\
\hline
\end{tabular}

Source: Author's estimations.

$1 /$ P-values in parenthesis. *, ** and *** denote significant at 10 percent, 5 percent, and 1 percent level. The dependent variable is the log of imports of country $i$ from country $j$. 
Table 6. Pooled Estimations of the Gravity Model: Gross Intra-Trade Effects, 1984-2005 1/

\begin{tabular}{|c|c|c|c|c|}
\hline & $\begin{array}{c}\text { Regression } \\
\text { (1) }\end{array}$ & $\begin{array}{c}\text { Regression } \\
(2) \\
\end{array}$ & $\begin{array}{c}\text { Regression } \\
\text { (3) }\end{array}$ & $\begin{array}{c}\text { Regression } \\
\text { (4) }\end{array}$ \\
\hline ASEAN & $\begin{array}{c}1.466 \\
(0.000)^{\star \star \star}\end{array}$ & $\begin{array}{l}\ldots \\
\ldots\end{array}$ & $\begin{array}{c}0.713 \\
(0.000)^{\star \star \star}\end{array}$ & $\begin{array}{c}0.537 \\
(0.000)^{\star \star \star \star}\end{array}$ \\
\hline CER & $\begin{array}{c}1.733 \\
(0.001)^{\star \star \star}\end{array}$ & $\begin{array}{c}1.773 \\
(0.000)^{\star \star \star}\end{array}$ & $\begin{array}{l}0.825 \\
0.101\end{array}$ & $\begin{array}{l}0.778 \\
0.119\end{array}$ \\
\hline SAPTA & $\begin{array}{c}0.937 \\
(0.000)^{\star \star \star}\end{array}$ & $\begin{array}{c}0.895 \\
(0.000)^{\star \star \star}\end{array}$ & $\begin{array}{c}0.99 \\
(0.000)^{\star \star \star}\end{array}$ & $\begin{array}{c}1.071 \\
(0.000)^{\star \star \star}\end{array}$ \\
\hline ASEAN-6 & $\begin{array}{l}\cdots \\
\cdots\end{array}$ & $\begin{array}{c}1.837 \\
(0.000)^{\star \star \star}\end{array}$ & $\begin{array}{l}\cdots \\
\cdots\end{array}$ & $\begin{array}{l}\cdots \\
\cdots\end{array}$ \\
\hline APEC & $\begin{array}{l}\cdots \\
\cdots\end{array}$ & $\begin{array}{l}\cdots \\
\cdots\end{array}$ & $\begin{array}{c}1.556 \\
(0.000)^{\star \star \star}\end{array}$ & $\begin{array}{c}2.093 \\
(0.000)^{\star \star \star}\end{array}$ \\
\hline EU-15 & $\begin{array}{l}\cdots \\
\ldots\end{array}$ & $\begin{array}{l}\ldots \\
\ldots\end{array}$ & $\begin{array}{l}\ldots \\
\ldots\end{array}$ & $\begin{array}{l}0.077 \\
0.259\end{array}$ \\
\hline EAEC & $\begin{array}{l}\cdots \\
\cdots\end{array}$ & $\begin{array}{l}\cdots \\
\cdots\end{array}$ & $\begin{array}{l}\cdots \\
\cdots\end{array}$ & $\begin{array}{c}2.325 \\
(0.000)^{\star \star \star}\end{array}$ \\
\hline Mercosur & $\begin{array}{l}\cdots \\
\cdots\end{array}$ & $\begin{array}{l}\cdots \\
\cdots\end{array}$ & $\begin{array}{l}\cdots \\
\cdots\end{array}$ & $\begin{array}{c}1.379 \\
(0.000)^{\star \star \star}\end{array}$ \\
\hline NAFTA & $\begin{array}{l}\ldots \\
\ldots \\
\end{array}$ & $\begin{array}{l}\ldots \\
\ldots\end{array}$ & $\begin{array}{l}\ldots \\
\ldots \\
\end{array}$ & $\begin{array}{c}-1.287 \\
(0.001)^{\star \star \star}\end{array}$ \\
\hline
\end{tabular}

Source: Author's estimations.

$1 /$ P-values in parenthesis. * ${ }^{* \star}$ and ${ }^{* *}$ denote significant at 10 percent, 5 percent, and 1 percent level. The dependent variable is the $\log$ of imports of country $i$ from country $j$. The gross intra-trade effect is defined as the sum of the three coefficients of each RTA provided in Table 5. In the case of ASEAN in Regression 1, the value 1.466 corresponds to the sum of the three coefficients of the ASEAN dummies in Regression 1, Table 5: $(-0.473+1.256+0.683)=1.466$ 
Table 7. Cross-Section Estimations of the Gravity Model with Importers-and Exporters-Fixed Effects, 1984-2005 1/

\begin{tabular}{|c|c|c|c|c|c|c|c|c|c|c|c|c|c|c|c|c|}
\hline & \multirow[t]{2}{*}{1984} & \multirow[t]{2}{*}{1987} & \multirow[t]{2}{*}{1990} & \multirow[t]{2}{*}{1993} & \multicolumn{2}{|c|}{1996} & \multicolumn{2}{|c|}{1999} & \multicolumn{2}{|c|}{2002} & \multicolumn{2}{|c|}{2003} & \multicolumn{2}{|c|}{2004} & \multicolumn{2}{|c|}{2005} \\
\hline & & & & & $A$ & $B$ & $A$ & B & $\mathrm{A}$ & $\mathrm{B}$ & $A$ & $B$ & $\mathrm{~A}$ & $B$ & $A$ & $B$ \\
\hline \multirow[t]{2}{*}{ longed i } & 0.851 & 0.825 & 1.032 & 0.908 & 0.859 & 0.859 & 0.897 & 0.897 & 0.892 & 0.891 & 0.930 & 0.930 & 0.919 & 0.920 & 0.958 & 0.958 \\
\hline & $(0.000)^{\star \star \star}$ & $(0.000)^{\star \star \star}$ & $(0.000)^{\star \star \star}$ & $(0.000)^{\star \star \star}$ & $(0.000)^{\star \star \star}$ & $(0.000)^{\star \star \star}$ & $(0.000)^{\star \star \star}$ & $(0.000)^{\star \star \star}$ & $(0.000)^{\star \star \star \star}$ & $(0.000)^{\star \star \star}$ & $(0.000)^{\star \star \star}$ & $(0.000)^{\star \star \star}$ & $(0.000)^{\star \star \star}$ & $(0.000)^{\star \star \star}$ & $(0.000)^{\star \star \star}$ & $(0.000)^{\star \star \star}$ \\
\hline \multirow[t]{2}{*}{ InGDP j } & 0.969 & 0.996 & 0.856 & 1.07 & 1.033 & 1.041 & 1.072 & 1.078 & 1.068 & 1.073 & 1.084 & 1.090 & 1.101 & 1.106 & 1.148 & 1.155 \\
\hline & $(0.000)^{\star \star \star}$ & $(0.000)^{\star \star \star}$ & $(0.000)^{\star \star \star}$ & $(0.000)^{\star \star \star}$ & $(0.000)^{\star \star \star}$ & $(0.000)^{\star \star \star}$ & $(0.000)^{\star \star \star}$ & $(0.000)^{\star \star \star}$ & $(0.000)^{\star \star \star \star}$ & $(0.000)^{\star \star \star}$ & $(0.000)^{\star \star \star}$ & $(0.000)^{\star \star \star}$ & $(0.000)^{\star \star \star}$ & $(0.000)^{\star \star \star}$ & $(0.000)^{\star \star \star \star}$ & $(0.000)^{\star \star \star}$ \\
\hline \multirow[t]{2}{*}{ InGDP i per capita } & 0.163 & 0.18 & 0.166 & 0.097 & 0.129 & 0.122 & 0.092 & 0.085 & 0.059 & 0.056 & 0.035 & 0.030 & 0.044 & 0.040 & 0.025 & 0.022 \\
\hline & $(0.000)^{\star \star \star}$ & $(0.000)^{\star \star \star}$ & $(0.000)^{\star \star \star}$ & $(0.000)^{\star \star \star}$ & $(0.000)^{\star \star \star}$ & $(0.000)^{\star \star \star \star}$ & $(0.000)^{\star \star \star}$ & $(0.000)^{\star \star \star}$ & $(0.000)^{\star \star \star \star}$ & $(0.000)^{\star \star \star}$ & $(0.006)^{\star \star \star}$ & $(0.017)^{\star \star}$ & $(0.000)^{\star \star \star}$ & $(0.001)^{\star \star \star}$ & $(0.068)^{\star}$ & -0.113 \\
\hline \multirow[t]{2}{*}{ InGDP j per capita } & 0.184 & 0.175 & 0.169 & 0.122 & 0.164 & 0.140 & 0.121 & 0.100 & 0.120 & 0.108 & 0.105 & 0.085 & 0.124 & 0.106 & 0.149 & 0.128 \\
\hline & $(0.000)^{\star \star \star}$ & $(0.000)^{\star \star \star}$ & $(0.000)^{\star \star \star}$ & $(0.000)^{\star \star \star}$ & $(0.000)^{\star \star \star}$ & $(0.000)^{\star \star \star}$ & $(0.000)^{\star \star \star}$ & $(0.000)^{\star \star \star}$ & $(0.000)^{\star \star \star}$ & $(0.000)^{\star \star \star}$ & $(0.000)^{\star \star \star}$ & $(0.000)^{\star \star \star}$ & $(0.000)^{\star \star \star}$ & $(0.000)^{\star \star \star}$ & $(0.000)^{\star \star \star}$ & $(0.000)^{\star \star \star}$ \\
\hline \multirow[t]{2}{*}{ In distance } & -1.285 & -1.258 & -1.280 & -1.343 & -1.356 & -1.338 & -1.333 & -1.322 & -1.319 & -1.301 & -1.325 & -1.314 & -1.343 & -1.336 & -1.422 & -1.415 \\
\hline & $(0.000)^{\star \star \star}$ & $(0.000)^{\star \star \star}$ & $(0.000)^{\star \star \star}$ & $(0.000)^{\star \star \star \star}$ & $(0.000)^{\star \star \star}$ & $(0.000)^{\star \star \star \star}$ & $(0.000)^{\star \star \star}$ & $(0.000)^{\star \star \star}$ & $(0.000)^{\star \star \star \star}$ & $(0.000)^{\star \star \star}$ & $(0.000)^{\star \star \star \star}$ & $(0.000)^{\star \star \star}$ & $(0.000)^{\star \star \star}$ & $(0.000)^{\star \star \star}$ & $(0.000)^{\star \star *}$ & $(0.000)^{\star \star \star}$ \\
\hline \multirow[t]{2}{*}{ common border } & -0.106 & 0.006 & 0.364 & 0.461 & 0.718 & 0.737 & 0.773 & 0.792 & 0.743 & 0.761 & 0.799 & 0.825 & 0.8 & 0.826 & 0.753 & 0.767 \\
\hline & -0.536 & -0.968 & $(0.015)^{\star \star}$ & $(0.000)^{\star \star \star}$ & $(0.000)^{\star \star \star}$ & $(0.000)^{\star \star \star}$ & $(0.000)^{\star \star \star}$ & $(0.000)^{\star \star \star}$ & $(0.000)^{\star \star \star \star}$ & $(0.000)^{\star \star \star}$ & $(0.000)^{\star \star \star}$ & $(0.000)^{\star \star \star}$ & $(0.000)^{\star \star \star}$ & $(0.000)^{\star \star \star}$ & $(0.000)^{\star \star \star}$ & $(0.000)^{\star \star \star}$ \\
\hline common language & 0.681 & 0.827 & 0.82 & 0.898 & 0.932 & 0.908 & 0.881 & 0.856 & 0.956 & 0.941 & 1.030 & 1.001 & 1.054 & 1.027 & 1.184 & 1.157 \\
\hline & $(0.000)^{\star \star \star}$ & $(0.000)^{\star \star \star}$ & $(0.000)^{\star \star \star}$ & $(0.000)^{\star \star \star \star}$ & $(0.000)^{\star \star \star}$ & $(0.000)^{\star \star \star \star}$ & $(0.000)^{\star \star \star}$ & $(0.000)^{\star \star \star}$ & $(0.000)^{\star \star \star \star}$ & $(0.000)^{\star \star \star}$ & $(0.000)^{\star \star \star *}$ & $(0.000)^{\star \star \star}$ & $(0.000)^{\star \star \star}$ & $(0.000)^{\star \star \star}$ & $(0.000)^{\star \star \star \star}$ & $(0.000)^{\star \star \star}$ \\
\hline ASEAN imp & 0.254 & 0.642 & 0.947 & 0.882 & 0.61 & $\ldots$ & 0.733 & $\ldots$ & 0.513 & $\ldots$ & 0.598 & $\ldots$ & 0.705 & $\ldots$ & 0.731 & ... \\
\hline & $(0.023)^{\star *}$ & $(0.000)^{\star \star \star \star}$ & $(0.000)^{\star \star \star}$ & $(0.000)^{\star \star *}$ & $(0.000)^{\star \star \star}$ & $\ldots$ & $(0.000)^{\star \star \star}$ & $\ldots$ & $(0.000)^{\star \star \star}$ & $\ldots$ & $(0.000)^{\star \star \star}$ & $\ldots$ & $(0.000)^{\star \star \star}$ & $\ldots$ & $(0.000)^{\star \star \star}$ & $\ldots$ \\
\hline ASEAN exp & 0.590 & 0.953 & 0.893 & 1.189 & 1.187 & $\ldots$ & 1.312 & $\ldots$ & 1.291 & $\ldots$ & 1.378 & $\ldots$ & 1.488 & $\ldots$ & 1.630 & $\ldots$ \\
\hline & $(0.000)^{\star \star \star}$ & $(0.000)^{\star \star *}$ & $(0.000)^{\star \star \star}$ & $(0.000)^{\star \star \star *}$ & $(0.000)^{\star \star \star}$ & $\ldots$ & $(0.000)^{\star \star \star}$ & $\ldots$ & $(0.000)^{\star \star \star}$ & $\ldots$ & $(0.000)^{\star \star \star *}$ & $\ldots$ & $(0.000)^{\star \star \star *}$ & $\ldots$ & $(0.000)^{\star \star \star \star}$ & $\ldots$ \\
\hline ASEAN 2 & 0.655 & 0.443 & -0.135 & -0.443 & -0.403 & & -0.601 & $\ldots$ & -0.750 & $\ldots$ & -0.816 & $\ldots$ & -0.911 & $\ldots$ & -0.568 & $\ldots$ \\
\hline & 0.164 & 0.314 & 0.751 & 0.279 & 0.153 & $\ldots$ & $(0.023)^{\star \star}$ & . & $(0.009)^{\star \star}$ & $\ldots$ & $(0.002)^{\star \star}$ & $\ldots$ & $(0.002)^{\star \star}$ & 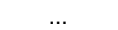 & $(0.074)^{\star}$ & . \\
\hline CER imp & -0.075 & -0.160 & 0.315 & 0.092 & -0.013 & -0.010 & 0.190 & 0.204 & -0.003 & -0.011 & 0.047 & 0.057 & -0.016 & -0.003 & 0.126 & 0.137 \\
\hline & 0.648 & 0.307 & $(0.025)^{\star \star}$ & 0.483 & 0.920 & 0.939 & 0.137 & 0.111 & 0.979 & 0.933 & 0.715 & 0.662 & 0.906 & 0.984 & 0.361 & 0.321 \\
\hline CER exp & 0.434 & 0.429 & -0.089 & 0.540 & 0.618 & 0.624 & 0.763 & 0.780 & 0.756 & 0.753 & 0.713 & 0.735 & 0.619 & 0.643 & 0.51 & 0.531 \\
\hline & $(0.006)^{\star \star \star}$ & $(0.004)^{\star \star \star}$ & 0.555 & $(0.000)^{\star \star \star}$ & $(0.000)^{\star \star \star}$ & $(0.000)^{\star \star \star}$ & $(0.000)^{\star \star \star}$ & $(0.000)^{\star \star \star}$ & $(0.000)^{\star \star \star \star}$ & $(0.000)^{\star \star \star}$ & $(0.000)^{\star \star \star}$ & $(0.000)^{\star \star \star}$ & $(0.000)^{\star \star \star \star}$ & $(0.000)^{\star \star \star}$ & $(0.000)^{\star \star \star \star}$ & $(0.000)^{\star \star \star}$ \\
\hline CER 2 & 1.609 & 1.52 & 1.359 & 1.266 & 0.968 & 1.019 & 0.969 & 1.005 & 1.098 & 1.15 & 0.837 & 0.875 & 0.729 & 0.754 & 0.457 & 0.483 \\
\hline & 0.351 & 0.347 & 0.386 & 0.397 & 0.523 & 0.503 & 0.520 & 0.506 & 0.479 & 0.460 & 0.586 & 0.568 & 0.653 & 0.643 & 0.791 & 0.780 \\
\hline SAPTA imp & $\ldots$ & $\ldots$ & $\ldots$ & $\ldots$ & 0.253 & 0.236 & 0.037 & 0.02 & -0.047 & -0.055 & 0.10 & 0.095 & 0.221 & 0.220 & 0.1 & 0.175 \\
\hline & $\ldots$ & $\ldots$ & $\ldots$ & $\ldots$ & $(0.007)^{\star \star \star}$ & $(0.011)^{\star \star}$ & 0.683 & 0.755 & 0.599 & 0.5 & 0.27 & 0.3 & $(0.015)^{\star \star}$ & $(0.016)^{\star \star}$ & $(0.065)^{\star}$ & $(0.075)^{\star}$ \\
\hline SAPTA exp & $\ldots$ & $\ldots$ & $\ldots$ & $\ldots$ & 0.690 & 0.625 & 0.447 & 0.400 & 0.473 & 0.441 & 0.592 & 0.550 & 0.552 & 0.512 & 0.706 & 0.655 \\
\hline & $\ldots$ & $\ldots$ & $\ldots$ & $\ldots$ & $(0.000)^{\star \star \star *}$ & $(0.000)^{\star \star \star *}$ & $(0.000)^{\star \star \star *}$ & $=(0.000)^{\star \star \star \star}$ & $(0.000)^{\star \star \star \star}$ & $(0.000)^{\star \star \star \star}$ & $(0.000)^{* \star *}$ & $(0.000)^{\star \star \star \star}$ & $(0.000)^{\star \star \star *}$ & $(0.000)^{\star \star \star \star}$ & $(0.000)^{\star \star \star}$ & $(0.000)^{* \star \star *}$ \\
\hline SAPTA 2 & $\ldots$ & $\ldots$ & $\ldots$ & $\ldots$ & 0.282 & 0.305 & 0.362 & 0.369 & 0.257 & & -0.094 & -0.0 & -0.0 & & & 0.028 \\
\hline & $\ldots$ & $\ldots$ & $\ldots$ & $\ldots$ & 0.517 & $0.4 \varepsilon$ & 0.405 & 0.3 & 0.572 & 0.5 & 0.849 & 0.8 & 0.935 & 0.929 & 0.963 & 0.956 \\
\hline ASEAN-6 imp & $\ldots$ & $\ldots$ & $\ldots$ & $\ldots$ & & 0.62 & $\ldots$ & 0.865 & $\ldots$ & 0.47 & $\ldots$ & 0.6 & $\ldots$ & 0.819 & $\ldots$ & 0.878 \\
\hline & $\ldots$ & $\ldots$ & $\ldots$ & $\ldots$ & & $(0.000)^{\star \star \star \star}$ & $\ldots$ & $(0.000$ & $\ldots$ & $(0.00$ & $\ldots$ & $(0.00$ & $\ldots$ & $(0.000)^{\star \star \star}$ & $\ldots$ & $(0.000)^{\star \star \star}$ \\
\hline ASEAN-6 exp & $\ldots$ & $\ldots$ & $\ldots$ & $\ldots$ & & 1.097 & $\ldots$ & 1.382 & $\ldots$ & 1.235 & $\ldots$ & 1.446 & $\ldots$ & 1.588 & $\ldots$ & 1.677 \\
\hline & $\ldots$ & $\ldots$ & & $\ldots$ & & $(0.000)^{* \star *}$ & $\ldots$ & $(0.000)^{\star \star \star \star}$ & $\ldots$ & $(0.000)^{\star \star \star *}$ & $\ldots$ & $(0.000)^{\star \star \star *}$ & $\ldots$ & $(0.000)^{\star \star \star}$ & $\ldots$ & $(0.000)^{* \star *}$ \\
\hline ASEAN-6 2 & $\ldots$ & $\ldots$ & $\ldots$ & $\ldots$ & $\ldots$ & -0.383 & $\ldots$ & -0.319 & $\ldots$ & 0.30 & $\ldots$ & -0.2 & $\ldots$ & -0.457 & $\ldots$ & -0.581 \\
\hline & $\ldots$ & $\ldots$ & $\ldots$ & $\ldots$ & & 0.3 & & 0.4 & & 0.4 & & 0.6 & & 0.2 & & 0.2 \\
\hline WTO imp & $\ldots$ & $\ldots$ & $\ldots$ & $\ldots$ & -0.512 & -0.530 & -0.339 & -0.374 & -0.176 & -0.2 & -0.149 & -0.2 & -0.185 & -0.2 & -0.1 & -0.189 \\
\hline & $\ldots$ & $\ldots$ & $\ldots$ & $\ldots$ & $(0.000)^{\star \star \star}$ & & $(0.000)^{\star \star \star}$ & $=(0.00$ & $(0.07$ & $(0.01$ & 0.1 & $(0.0$ & 0.1 & $(0.0$ & 0.2 & 0.18 \\
\hline WTO exp & $\ldots$ & $\ldots$ & $\ldots$ & $\ldots$ & -0.470 & -0.499 & -0.245 & -0.301 & 0.049 & -0.0 & 0.05 & -0.0 & -0.047 & -0.111 & -0.018 & -0.078 \\
\hline & & $\ldots$ & & $\ldots$ & $(0.000)^{\star \star \star}$ & $(0.000)^{\star \star \star}$ & $(0.002)^{\star \star \star *}$ & $(0.000)^{\star \star \star *}$ & 0.620 & 0.530 & 0.650 & 0.594 & 0.695 & 0.353 & 0.900 & 0.579 \\
\hline WTO 2 & $\ldots$ & $\ldots$ & $\ldots$ & $\ldots$ & 0.721 & 0.725 & 0.505 & 0.512 & 0.372 & 0.409 & 0.301 & 0.329 & 0.459 & 0.447 & 0.420 & 0.396 \\
\hline & & & & & $(0.000)^{\star \star \star *}$ & $(0.000)^{\star}$ & $(0.000)^{\star \star \star}$ & $(0.000)^{\star \star \star}$ & $(0.001)^{\star \star \star \star}$ & $(0.000)^{\star *}$ & $(0.014)^{\star \star}$ & $(0.007)^{\star}$ & $(0.000)^{\star \star \star}$ & $(0.000)^{\star \star \star *}$ & $(0.005)^{\star \star \star}$ & $(0.008)^{\star \star \star}$ \\
\hline Constant & 12.915 & 12.319 & 12.14 & 12.308 & 12.76 & 12.68 & 12.18 & 12.18 & 11.80 & 11.7 & 11.55 & 11.62 & 11.45 & 11.50 & 11.55 & 11.60 \\
\hline & $(0.000)^{* \star *}$ & $(0.000)^{\star \star \star}$ & $(0.000)^{\star \star \star *}$ & & $(0.000)^{\star \star \star}$ & & $(0.000)^{\star \star \star}$ & & & & $(0.000)^{\star * \star *}$ & & $(0.000)^{* \star *}$ & & & $(0.000)^{\star \star \star}$ \\
\hline Observation & 10,545 & 10,991 & 11,694 & 14,978 & 19,340 & 19,340 & 19,406 & 19,406 & 21,222 & 21,222 & 18,942 & 18,942 & 21,205 & 21,205 & 20,747 & 20,747 \\
\hline Adj. R-squared & 0.55 & 0.61 & 0.64 & 0.67 & 0.67 & 0.67 & 0.68 & 0.68 & 0.67 & 0.67 & 0.68 & 0.68 & 0.67 & 0.67 & 0.66 & 0.66 \\
\hline
\end{tabular}

$1 /$ P-values in parenthesis. *, ** and ${ }^{* * *}$ denote significant at 10 percent, 5 percent, and 1 percent level. The dependent variable is the log of imports of country $i$ from country $j$. ASEAN dummies through 1993 include ASEAN-6 countries only, as they were the only members of ASEAN. Starting from 1996 the specifications A and B differ only in that the first includes the dummy on ASEAN countries according to the year of membership, while the second includes the dummy on ASEAN-6 countries, only. 
Figure 1. Preferential Trade Agreements in Force in the Asia and Pacific Region, February 2007

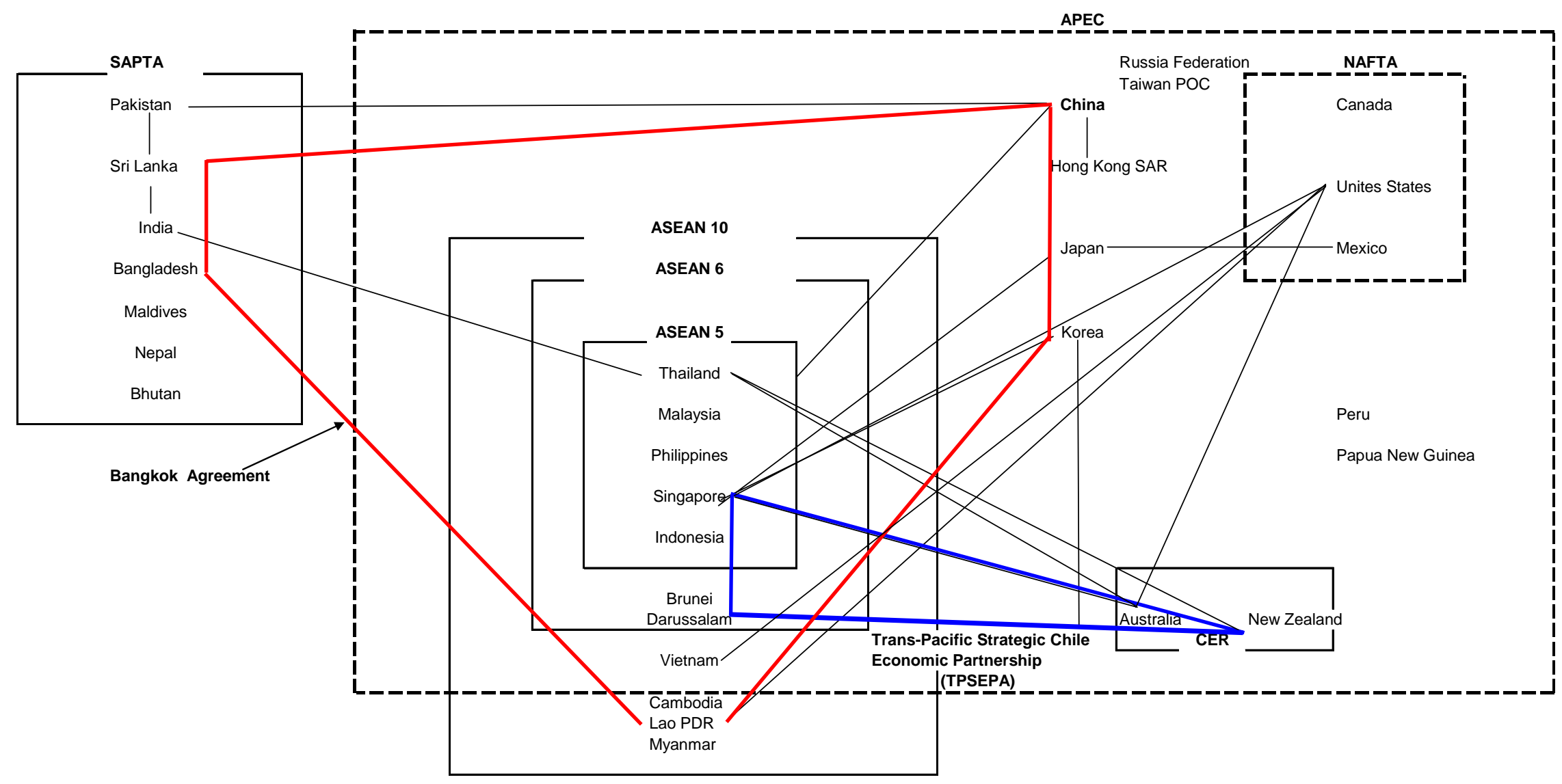

Note:

Bilateral and regional trade agreements within the Asia and Pacific region.

: Includes regional agreements with countries outside of the Asia and Pacific region. 
Figure 2A. Evolution of Exports within and Outside the Region, 1984-2005 (in billions of U.S. dollars)
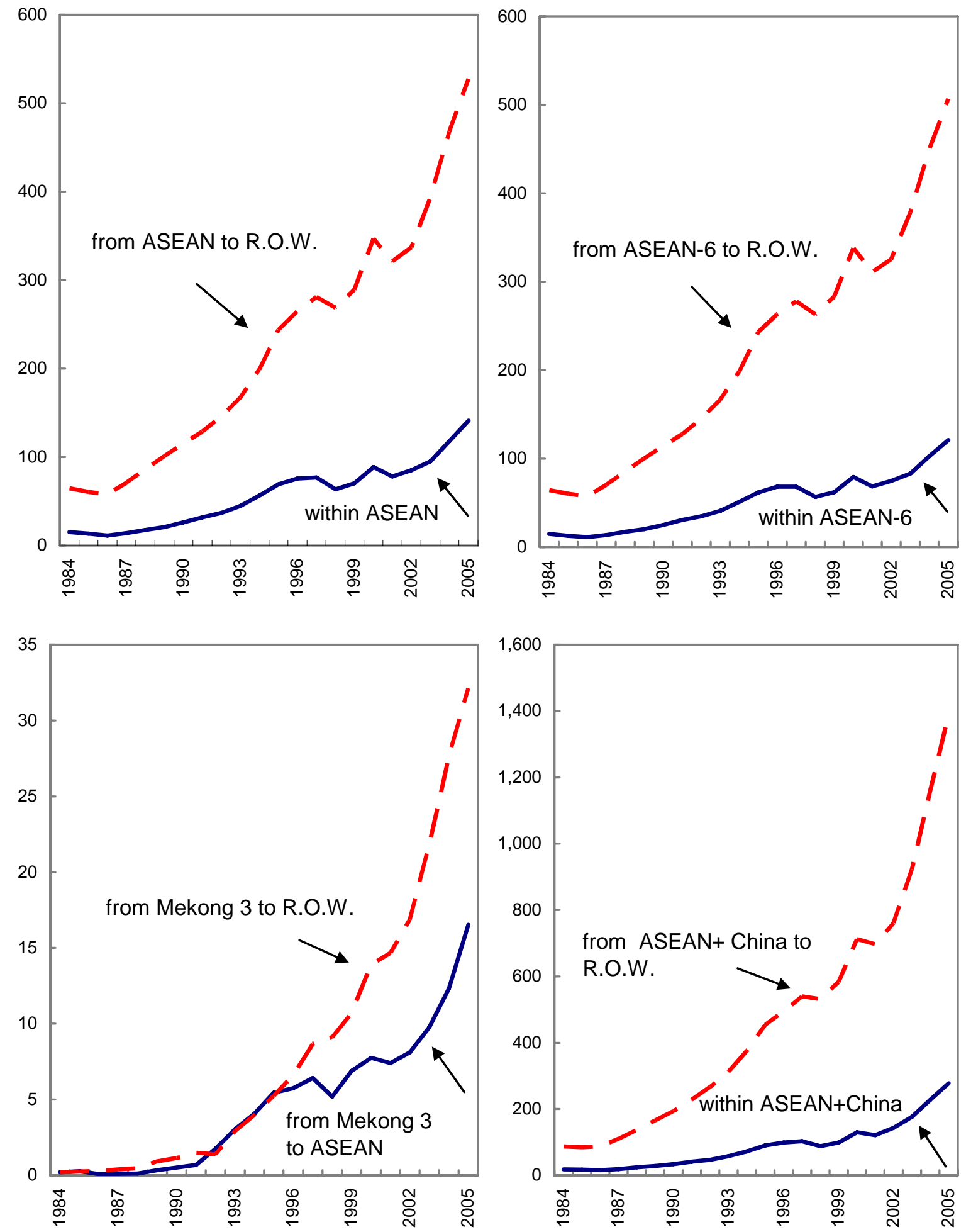

Source: Fund Staff estimates based on UN COMTRADE database. 
Figure 2B. Evolution of Exports within and Outside the Region, 1984-2005 (in billions of U.S. dollars)
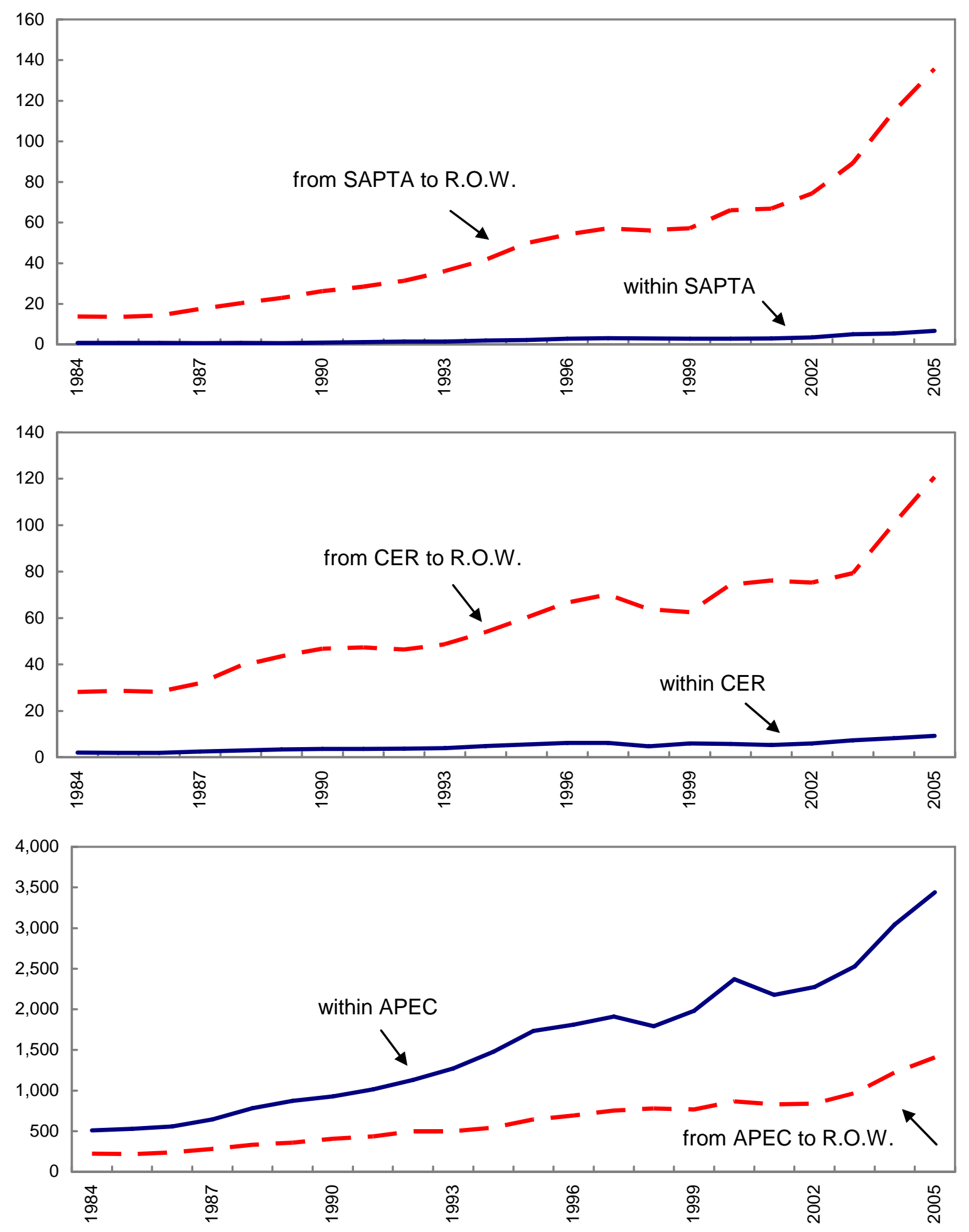

Source: Fund Staff estimates based on UN COMTRADE database. 


\section{References}

Anderson J. E., (1979), “The Theoretical Foundations of the Gravity Equation,” American Economic Review, Vol. 69, pp. 106-116.

Anderson J. E., and E. Wincoop (2003), "Gravity with Gravitas: A Solution to the Boarder Puzzle,” American Economic Review, Vol. 93, No 1, pp. 170-92.

Asian Development Bank, 2006, Asian Development Outlook 2006.

Baldwin, R., 1993, “A Domino Theory of Regionalism,” CEPR Discussion Paper No. 857, Center for Economic Policy Research.

Baldwin, R., 2006, “Managing the Noodle Bowl,” CEPR Discussion Paper No. 5561, London.

Bergstrand, J., 1985, “The Gravity Equation in International Trade: Some Microeconomic Foundations and Empirical Evidence,” Review of Economics and Statistics, 67:3, August, pp.474-81.

Brenton, P., 2003, “Rules of Origin in Free Trade Agreements,” Trade Note No. 4, The World Bank.

Clarete, R., C. Edmonds, and J. Seddon Wallack, 2002, “Asian Regionalism and Its Effects on Trade in the 1980s and 1990s,” Asian Development Bank, ERD Working Paper Series No. 30.

Dee, P., and J. Gali, 2003, “The Trade and Investment Effects of Preferential Trading Arrangements,” NBER Working Paper No. 10160, Cambridge, Massachusetts.

Deltas, G., K. Desmet, and G. Facchini, 2006, “Hub-and-Spoke Free Trade Areas,” CEPR Discussion Paper No. 5960, Center for Economic Policy Research.

Elliot, R., and K. Ikemoto, 2004, “AFTA and the Asia Crisis: Help or Hindrance to ASEAN Intra-Regional Trade?” Asian Economic Journal, Vol. 18, No. 1.

Feridhanusetyawan, T., 2005, "Preferential Trade Agreements in the Asia-Pacific Region,” IMF Working Paper 05/149 (Washington: International Monetary Fund).

Gosh, S., and S. Yamarik, 2004, “Are Regional Trading Arrangements Trade Creating? An Application to Extreme Bound Analysis,” Journal of International Economics, 63(2):369-395.

Haveman, J., and D. Hummels, 1998, “Trade Creation and Trade Diversion: New Empirical Results,” Journal of Transnational Management Development, 3(2), pp.42-72. 
Helpman, E., and P. Krugman, 1985, Market Structure and Foreign Trade, The MIT Press, Cambridge, Massachusetts.

Kimura, F., and M. Ando, 2005, “The Economic Analysis of International Production/Distribution Networks in East Asia and Latin America,” Business and Politics, Vol. 7, Issue 1.

Kimura, F., 2006, "International Production and Distribution Networks in East Asia: Eighteen Facts, Mechanics, and Policy Implications,” Asian Economic Policy Review, Vol. 1, Issue 2.

Krishna, P., 1998, "Regionalism and Multilateralism: A Political Economy Approach,” Quarterly Journal of Economics, Vol. 113 (No. 1, February).

Krueger, A., 1995, “Free Trade Agreements Versus Customs Unions,” National Bureau of Economic Research, NBER Working Paper No. 5084, Cambridge, Massachusetts. , 1997, “Problems with Overlapping Free Trade Areas,” in Regionalism versus Multilateral Trade Arrangements, ed. by T. Ito and A. Krueger, Chicago University Press.

Poyhonen, P., 1963, “A Tentative Model for the Volume of Trade Between Countries,” Welwirtschaftliches Archiv, 90(1): 93-99.

Rose, A.K., 2004, “Do We Really Know that the WTO Increases Trade?” American Economic Review, 94(1):98-114.

Soloaga, I., and A. Winters, 2001, “Regionalism in the Nineties: What Effect on Trade,” North American Journal of Economics and Finance, No. 12, pp. 1-29.

Subramanian, A, and S. Wei, 2003, “The WTO Promotes Trade, Strongly but Unevenly,” National Bureau of Economic Research, NBER Working Paper No. 10024, Cambridge, Massachusetts, forthcoming in the Journal of International Economics.

Tinbergen, J., 1962, Shaping the World Economy: Suggestions for an International Economics Policy, The Twentieth Century Fund, New York.

Tumbarello, P., 2005, "Regional Integration and WTO Accession: Which is the Right Sequencing? An Application to the CIS,” IMF Working Paper No. 05/94 (Washington: International Monetary Fund).

_ Investigation Using a Gravity Model,” in Vietnam: Selected Issues, Country Report 06/20, Chapter 2 (Washington: International Monetary Fund). 
Viner, J., 1950, The Custom Union Issue, Carnegie Endowment for International Peace, New York.

Wei S.J., 1996, “Intra-National Versus International Trade: How Stubborn are Nations in Global Integration?” NBER Working Paper No. 5531, Cambridge, Massachusetts.

Wei, S., and J. Frankel, 1997, “Open Versus Closed Regional Trade Blocs,” in Regionalism versus Multilateral Trade Arrangements, ed. by T. Ito and A. Krueger, Chicago University Press.

Wonnacott, P., 1996, "Beyond NAFTA - The Design of a Free Trade Agreement of the Americas,” in The Economics of Preferential Trade Agreements, 79-107, College Park: University of Maryland, Center for International Economics; Washington DC: AEI Press.

World Bank, 2005, Global Economic Prospects 2005: Trade, Regionalism and Development, Washington, D.C. 


\section{ANNEX I}

\section{Country Membership}

The Asia Pacific Economic Cooperation (APEC): Australia, Brunei Darussalam, Canada, Chile, China, Hong Kong SAR, Indonesia, Japan, Korea, Malaysia, Mexico, New Zealand, Papua New Guinea, Peru, the Philippines, Russia, Singapore, Taiwan Province of China, Thailand, the United States, and Vietnam.

Agreement on South Asian Association for Regional Cooperation (SAARC) Preferential Trading Arrangement (SAPTA): Bangladesh, Bhutan, India, Maldives, Nepal, Pakistan, and Sri Lanka.

Association of Southeast Asian Nations (ASEAN): Brunei Darussalam, Cambodia, Indonesia, Lao P.D.R., Malaysia, Myanmar, Philippines, Singapore, Thailand, and Vietnam.

ASEAN-6: Brunei Darussalam, Indonesia, Malaysia, Philippines, Singapore, and Thailand.

Bangkok Agreement: Bangladesh, China, Lao PDR, and Sri Lanka

Closer Economic Relation (CER): Australia and New Zealand.

Eurasian Economic Community (EAEC): Belarus, Kazakhstan, the Kyrgyz Republic, the Russian Federation, and Tajikistan.

European Union comprising 15 members (EU-15): Austria, Belgium, Denmark, Finland, France, Germany, Greece, Ireland, Italy, Luxembourg, the Netherlands, Portugal, Spain, Sweden, and the United Kingdom.

North American Free Trade Agreement (NAFTA): Canada, Mexico, and the United States.

Southern Common Market (Mercosur): Argentina, Brazil, Paraguay, and Uruguay.

Trans-Pacific Strategic Economic Partnership (TPSEPA): Brunei Darussalam, Chile, New Zealand, and Singapore. 


\section{ANNEX II}

Summary of Recent Empirical Literature on Trade Creation vs. Trade Diversion in Asia

\begin{tabular}{|c|c|c|}
\hline Author & Data and methodology & Results \\
\hline $\begin{array}{l}\text { Wei and Frankel } \\
1997\end{array}$ & $\begin{array}{l}\text { Gravity model } \\
\text { (annual cross-section } \\
\text { regressions); aggregate trade } \\
\text { data } 1960-90 .\end{array}$ & A positive intra-bloc coefficient for ASEAN. \\
\hline $\begin{array}{l}\text { Soloaga and } \\
\text { Winters (2001) }\end{array}$ & $\begin{array}{l}\text { Gravity model (annual cross- } \\
\text { section regressions); aggregate } \\
\text { trade data 1980-96. }\end{array}$ & $\begin{array}{l}\text { No evidence of trade diversion on ASEAN. } \\
\text { Negative intra-bloc coefficient for ASEAN. }\end{array}$ \\
\hline $\begin{array}{l}\text { Clarete, } \\
\text { Edmonds and } \\
\text { Wallack (2002) }\end{array}$ & $\begin{array}{l}\text { Gravity model (annual cross- } \\
\text { section regressions and panel } \\
\text { regressions), 1980-2000. }\end{array}$ & $\begin{array}{l}\text { A positive intra-bloc coefficient for SAPTA. No } \\
\text { evidence of intra-bloc trade effects on ASEAN } \\
\text { and CER, but evidence of import trade diversion } \\
\text { for ASEAN. APEC is fostering greater intra-bloc } \\
\text { trade as well as greater trade with the rest of the } \\
\text { world. }\end{array}$ \\
\hline $\begin{array}{l}\text { Dee and Gali } \\
(2003)\end{array}$ & $\begin{array}{l}\text { Gravity model (Tobit } \\
\text { estimation with country- } \\
\text { specific effects); aggregate } \\
\text { trade data 1970-97; instead of } \\
\text { a } 0-1 \text { dummy, the authors } \\
\text { calculated a member } \\
\text { liberalization index to capture } \\
\text { the degree of intra-RTA } \\
\text { liberalization. }\end{array}$ & $\begin{array}{l}\text { Net trade diversion and a negative intra-bloc trade } \\
\text { effect on ASEAN. }\end{array}$ \\
\hline $\begin{array}{l}\text { Elliot and } \\
\text { Ikemoto (2004) }\end{array}$ & $\begin{array}{l}\text { Gravity model (pooled } \\
\text { regression); aggregate trade } \\
\text { data 1983-99. }\end{array}$ & $\begin{array}{l}\text { Found evidence of trade creation, but little } \\
\text { evidence of trade diversion on ASEAN. }\end{array}$ \\
\hline $\begin{array}{l}\text { Gosh and } \\
\text { Yamarik (2004) }\end{array}$ & $\begin{array}{l}\text { Gravity model (pooled } \\
\text { regression); extreme bounds } \\
\text { analysis to test the robustness } \\
\text { of trade creation hypothesis; } \\
\text { aggregate trade data 1970-95 } \\
\text { in 5-year interval. }\end{array}$ & $\begin{array}{l}\text { Some evidence of trade creation, but not robust } \\
\text { under extreme bounds analysis; little evidence of } \\
\text { trade diversion on ASEAN. }\end{array}$ \\
\hline
\end{tabular}

